\title{
IMPELEMENTASI ALGORITMA REGRESI LINIER BERGANDA UNTUK PREDIKSI PENJUALAN
}

\author{
Yaya Asohi ${ }^{1}$, Andri $^{2}$, \\ ${ }^{1,2}$ Fakultas Ilmu Komputer, Universitas Bina Darma, Palembang, Indonesia \\ Email: yayaasohi1212@gmail.com ${ }^{1}$, andri@ binadarma.ac.id ${ }^{2}$
}

\begin{abstract}
Minimarket is a place or shop that sells various kinds of basic necessities of the community and generally uses technology or a machine to make payment transactions. The problem that is often faced in minimarkets is the uncertainty of the number of sales, it is also faced by Minimarket Sr. This study aims to predict the number of sales of goods using multiple linear regression algorithms as a method to be applied to predict. The results obtained from this study resulted in the predicted number of sales of goods for 2020 amounting to 169715 items.
\end{abstract}

Keywords: Minimarket, Prediction, Multiple Linear Regression Algorithm

\begin{abstract}
Abstrak
Minimarket merupakan sebuah tempat atau toko yang menjual berbagai macam barang kebutuhan pokok masyarakat dan umumnya menggunakan teknologi atau sebuah mesin untuk melakukan transaksi pembayarannya. Permasalahan yang sering dihadapi pada minimarket yakni tidak menentunya jumlah penjualan, hal itu juga yang dihadapi oleh Minimarket Sr. Penelitian ini bertujuan untuk memprediksi jumlah penjualan barang menggunakan algoritma regresi linier berganda sebagai metode yang akan diterapkan untuk memprediksi. Hasil yang didapatkan dari penelitian ini menghasilkan jumlah prediksi penjulan barang untuk tahun 2020 sebesar 169715 barang.
\end{abstract}

Kata Kunci: Minimarket, Prediction, Algoritma Regresi Linier Berganda

\section{Pendahuluan}

Transaksi jual beli merupakan kegiatan yang dilakukan manusia untuk memenuhi kebutuhan pokok mereka, kegiatan ini dapat dilakukan baik secara langsung bertatap muka maupun secara tidak langsung atau secara online. Kegiatan transaksi jual beli umumnya dilakukan disuatu tempat yang sering disebut sebagai toko.

Minimarket merupakan tempat atau toko yang menjual berbagai macam barang kebutuhan pokok masyarakat dan umumnya menggunakan teknologi atau sebuah mesin untuk melakukan transaksi pembayarannya [1]. Minimarket Sr merupakan salah satu perusahaan minimarket yang berada di Indonesia, dalam mengelola sebuah minimarket dibutuhkan manajemen atau tatakelola yang baik agar minimarket bisa terus berkembang maju, salah satu permasalahan yang sering dialami oleh usaha minimarket adalah belum adanya kepastian jumlah penjualan barang, akankah kedepannya terjadi kenaikan maupun penurunan jumlah penjualan barang. Salah satu solusi untuk menyelesaikan permasalahan ini yakni dengan melakukan prediksi jumlah penjualan barang.

Algoritma Regresi Linier Berganda merupakan teknik algoritma regresi linier yang memiliki jumlah variabel bebas $\mathrm{X} 1, \mathrm{X} 2, \mathrm{Xn}$ lebih dari satu dan dapat memiliki keterkaitan serta dapat mempengaruhi dari variabel $\mathrm{Y}$, dimana variabel $\mathrm{Y}$ adalah satu variabel yang tidak bebas, tujuan dari algoritma ini yakni untuk memprediksi variabel Y [2] . 
Penelitian ini akan menggunakan Algoritma Regresi Linier Berganda, hal ini dikarenakan data yang akan diolah untuk memprediksi penjualan memliki nilai 2 variabel bebas yakni X1 dan X2 dan memiliki satu variabel tidak bebas Y.

\section{Metodologi Penelitian}

\subsection{Alur Penelitian}

Penelitian ini menggunakan tahapan data mining dengan metode Knowledge Discovery in Database (KDD), adapaun pengertian dari KDD yaitu suatu penjelasan mengenai proses penggalian informasi yang tersembunyi di dalam suatu kumpulan data yang besar [3]. Selain itu Istilah knowledge discovery in database (KDD) juga digunakan untuk memberi penjelasan mengenai proses pencarian informasi yang belum diketahui di dalam suatu basis data yang besar [4]. Adapun tahapan prosesnya antara lain:

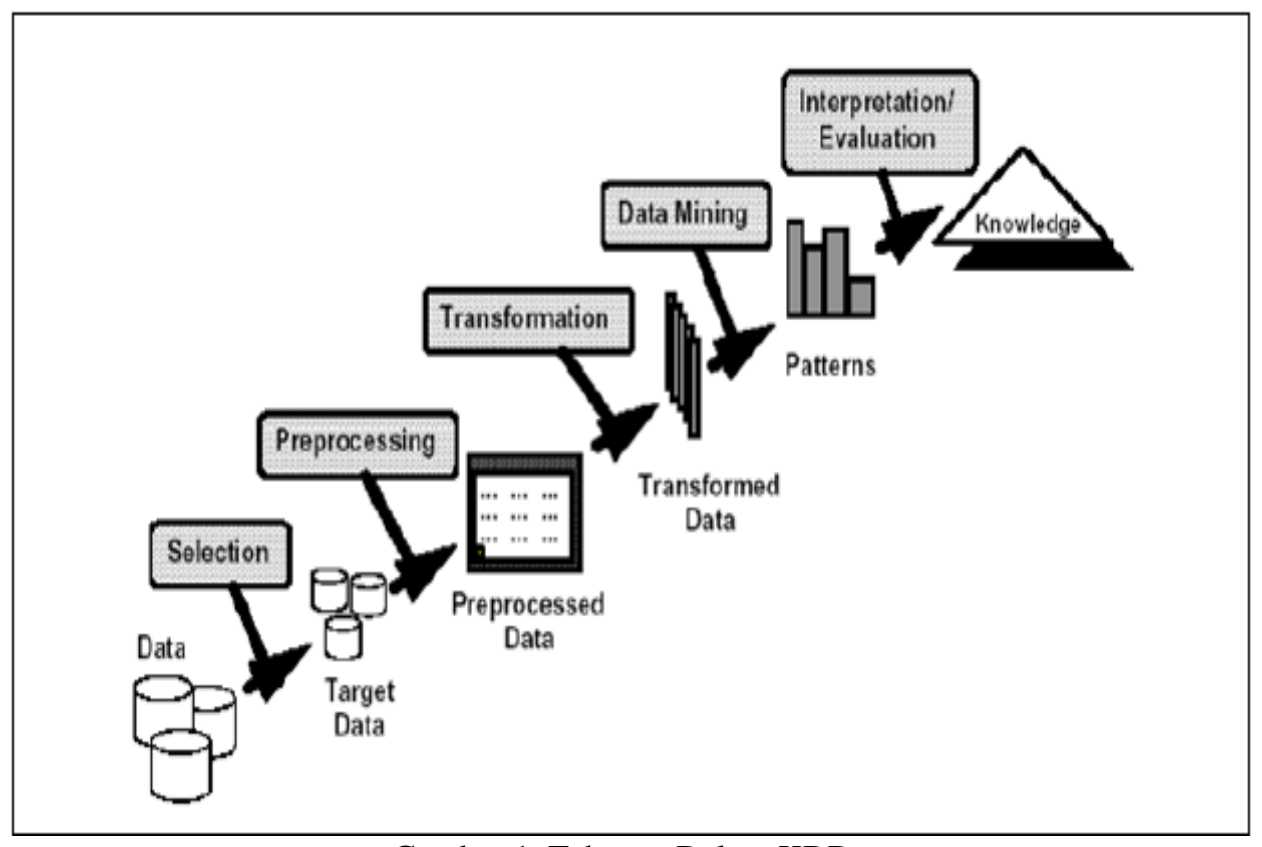

Gambar 1. Tahapan Dalam KDD

a. Seleksi data (selection), merupakan kegiatan menyeleksi atau memilih data dari kumpulan data, proses ini dilakukan untuk memilah data berdasarkan kebutuhan dalam proses penelitihan.

b. Pra-pemrosesan (Pre-processing) dan pembersihan (Cleaing), pada proses ini dilakukan pembersihan data, adapun proses pembersihan data tersebut yakni dilakukannya pemeriksaan data yang bersifat inconsistent, menghapus data yang sama serta memperbaiki kesalahan pada data.

c. Transformasi data, pada tahapan ini dilakukan proses penggabungan data yang dipilih berdasarkan kebutuhan penelitian, dimana data tersebut selanjutkan akan di proses pada data mining

d. Data mining, pada proses ini dilakukan pencarian pola atau pengetahuan yang sebelumnya belum diketahui di dalam suatu data pilihan menggunakan metode tertentu.

e. Evaluasi, kegiatan mengartikan pola yang diperoleh dari tahapan data mining, dimana pola yang dihasilkan dari proses data mining tersebut perlu ditunjukan didalam bentuk yang bisa di mengerti oleh pengguna.

\subsection{Prediksi (Forecasting)}

Prediksi merupakan suatu jenis kegiatan untuk memperkirakan sesuatu yang akan terjadi dimasa depan. Perasalahan dalam proses menentukan keputusan adalah kendala yang dihadapi, oleh sebab itu prediksi termasuk dari permasalah yang harus dihadapi, dikarenakan prediksi memiliki keterkaitan dengan pengambilan keputusan [5]. 


\subsection{Data Mining}

Data mining adalah penggalian data yang bertujuan untuk mendapatkan informasi yang berguna dari database. Penggalian data juga bisa diartikan sebagai pencarian informasi baru yang di daapatkan dari data dalam jumlah besar, untuk membantu dalam pengambilan keputusan [6]. Data mining adalah suatu kegiatan yang mendukung dalam pemilihan keputusan yang mana kita mencari pola informasi dalam data, proses pencarian ini dapat dilakukan oleh pengguna dengan bantuan suatu aplikasi yang secara otomatis dapat mencari pola informasi dari basis data [7].

\subsection{Regresi Linier Berganda}

Algoritma Regresi linier memiliki keterkaitan secara linear antara dua atau lebih variabel yang bebas (independen) X1, X2, .Xn dengan variabel yang tidak bebas (dependen) Y. Dalam mencari nilai dari variable regresi \& konstanta, variabel bebas bisa didapatkan dari matriks determinan [8]. Adapun rumusnya antara lain:

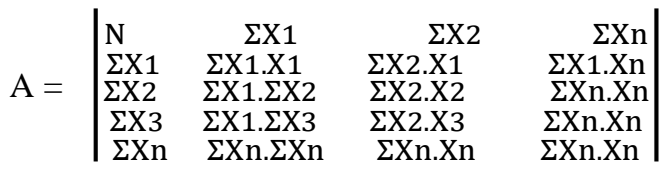

$$
\begin{aligned}
& B=\left|\begin{array}{c}
b 0 \\
b 1 \\
b 2 \\
b n
\end{array}\right| \\
& \mathrm{H}=\left|\begin{array}{l}
\Sigma \mathrm{Y} \\
\Sigma \mathrm{Y} . \mathrm{X} 1 \\
\Sigma \mathrm{Y} . \mathrm{X} 2
\end{array}\right|
\end{aligned}
$$

Selanjutnya untuk menghasilkan nilai dari pada b1, b2 dan a, antara lain:

$$
\begin{gathered}
\mathrm{a}=\frac{\operatorname{Det}(\mathrm{A} 0)}{\operatorname{Det}(\mathrm{A})} \quad \mathrm{B} 1=\frac{\operatorname{Det}(\mathrm{A} 1)}{\operatorname{Det}(\mathrm{A})} \quad \mathrm{B} 2=\frac{\operatorname{Det}(\mathrm{A} 2)}{\operatorname{Det}(\mathrm{A})} \quad \mathrm{Bn}=\frac{\operatorname{Det}(\mathrm{An})}{\operatorname{Det}(\mathrm{A})} \\
(\mathrm{Y}=\mathrm{a}+\mathrm{b} 1 . \mathrm{X} 1+\mathrm{b} 2 . \mathrm{X} 2 \ldots+\mathrm{bn} . \mathrm{Xn})
\end{gathered}
$$

Yang mana:

$$
\begin{aligned}
& \mathrm{Y}=\text { Value dari Prediksi } \\
& \mathrm{A}=\text { Value dari konstanta } \\
& \mathrm{X} 1=\text { Value dari variabel bebas pertama } \\
& \mathrm{X} 2=\text { Value dari variabel bebas kedua } \\
& \mathrm{Xn}=\text { Value dari variabel bebas } \mathrm{n}
\end{aligned}
$$

\subsection{Rapidminer}

Rapidminer adalah sebuah perangkat lunak untuk mengelola data mining. Rapidminer dijadikan salah satu pilihan solusi untuk melakukan analisa terhadap data mining, text mining dan analisa prediksi. Pengunaan berbagai jenis teknis seperti teknik deskriptif serta prediksi pada rapidminer dapat memberikan pengetahuan kepada para pengguna sehingga bisa memberikan keputusan yang paling baik [9]. 


\section{Hasil dan Pembahasan}

\subsection{Proses Knowledge Discovery in Database (KDD)}

\subsubsection{Data Selection}

Pada proses ini data diseleksi berdasarkan atribut yang dibutuhkan untuk kegiatan data mining. Dalam tahapan seleksi data, alat yang digunakan yakni pentaho data integration. Berikut ini adalah tampilah dari proses data selection menggunakan alat pentaho data integration:

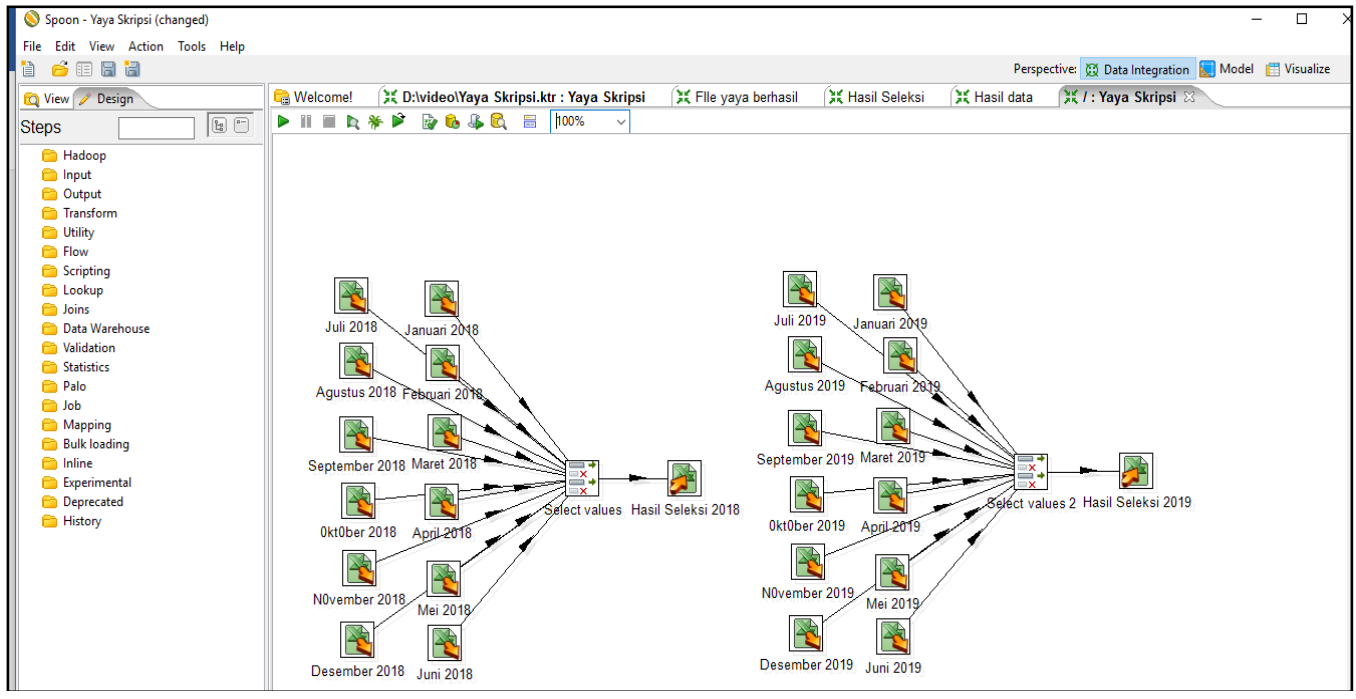

Gambar 2. Proses data selection

\subsubsection{Preprocessing}

Dalam tahapan ini dilakukan cleaning dan integration data. Adapun prosesnya antara lain:

Tabel 1. Sampel Dari Data Penjualan Yang Belum Dilakukan Cleaning Data

\begin{tabular}{|c|l|l|l|r|r|}
\hline NOMOR & N0 TRANSAKSI & \multicolumn{1}{|c|}{ TANGGAL } & \multicolumn{1}{|c|}{ NAMA_BARANG } & QT & HARGA \\
\hline 1 & BR R000001 & Januari - 18 & INDOMILK LIQ MELON BTL 190ML & 2 & 3,802 \\
\hline 2 & BR R000002 & Januari - 18 & PUCUK HARUM TEH PET 350ML 24 & 4 & 2,865 \\
\hline 3 & BR R000003 & Januari - 18 & GARUDA ROSTA K/P BW ANG 100G & 2 & 8,390 \\
\hline 4 & BR R000004 & Januari - 18 & NN FANTASY STK RAINBOW 22.5G/144 & 1 & 3,196 \\
\hline 5 & BR R000005 & Januari - 18 & ROTI SOBEK 6S PCS 1 & 3 & 8,000 \\
\hline 6 & BR R000006 & Januari - 18 & FRESTEA G.TEA MADU PET 500ML & 2 & 5,080 \\
\hline 172 & HPYR000076 & Januari - 18 & ABC SARDINES EXT PEDAS CAN 155G & -2 & 8,000 \\
\hline 213 & HPYR000081 & Januari - 18 & ABC KACANG HIJAU 250ML & -3 & 5,000 \\
\hline 222 & HPYR000081 & Januari - 18 & WALL'S P.POP CHOCO MAGMA 55ML & -2 & 0 \\
\hline 236 & HPYR000082 & Januari - 18 & ALIS OREZA & -1 & 10,000 \\
\hline 271 & HPYR000091 & Januari - 18 & GOON L30 & -1 & 52,163 \\
\hline 301 & HPYR000101 & Januari - 18 & CUSSONS BABY COTTON EXTRA & -1 & 5,000 \\
\hline 247192 & DR R037613 & Desember -2019 & DARK CHOCOLATE COMPOUND 250G & 2 & 18,000 \\
\hline & & & & & \\
\hline
\end{tabular}

Tahapan cleaning data bertujuan untuk menghapuskan data null, data yang sama serta data tidak konsisten, 
Tabel 2. Sampel Data Penjualan Yang Telah Dilakukan Cleaning

\begin{tabular}{|c|c|c|c|c|c|}
\hline NOMOR & NO TRANSAKSI & TANGGAL & NAMA_BARANG & QT & HARGA \\
\hline 1 & BR R000001 & Januari - 18 & INDOMILK LIQ MELON BTL 190ML & 2 & 3,802 \\
\hline 2 & BR R000OO2 & Januari - 18 & PUCUK HARUM TEH PET 350ML/24 & 4 & 2,865 \\
\hline 3 & BR R000003 & Januari - 18 & GARUDA ROSTA K/P BWANG 100G & 2 & 8,390 \\
\hline 4 & BR R000004 & Januari - 18 & NN FANTASY STK RAINBOW $22.5 \mathrm{G} / 144$ & 1 & 3,196 \\
\hline 5 & BR R000005 & Januari - 18 & ROTI SOBEK 6S PCS 1 & 3 & 8,000 \\
\hline 6 & BR R000006 & Januari - 18 & FRESTEA G.TEA MADU PET 500ML & 2 & 5,080 \\
\hline 7 & BR R000007 & Januari - 18 & FORTUNE PP 1 L/24 & 2 & 11,500 \\
\hline 8 & BR R000008 & Januari - 18 & PSM GULA PREMIUM $1 \mathrm{KG}$ & 2 & 12,500 \\
\hline 9 & BR R000008 & Januari - 18 & SUNLIGHT PLUS A.BAK REF 800ML & 1 & 17,075 \\
\hline 10 & BR R000009 & Januari - 18 & SGM EKSPLOR 1+ VANILLA 600 GR & 1 & 51,300 \\
\hline 11 & BR R000010 & Januari - 18 & BONEETO CHOCOLATE 350G & 1 & 39,165 \\
\hline 12 & BR R000011 & Januari - 18 & CB NIPPLE JAR MIX 18S & 1 & 5,108 \\
\hline 245244 & DS R037613 & Desember- 19 & BELFOODS SOSIS A YAM 375GR & 2 & 18,000 \\
\hline
\end{tabular}

Setelah dilakukannya proses cleaning data, hasil yang didapatkan yakni data penjualan yang sebelumnya berjumlah 247192 record, seteleah dilakukan cleaning data berubash menjadi 245244 record. Selanjutnya adalah proses integration data adapun prosesnya adalah sebagai berikut:

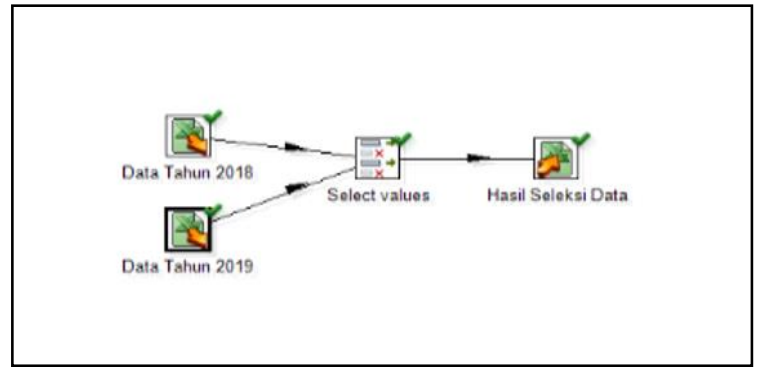

Gambar 3. Proses Data Integration

Pada tahapan dari Data Integration data dari berbagai sumber disatukan untuk keperluan dalam proses data mining.

\subsubsection{Data Trasnformation}

Dalam proses ini data diolah dan disesuiakan agar format dari data tersebut bisa dipakai dalam proses data mining.

Table 3. Sampel Data Yang Selesai Dilakukan Transformasi Data

\begin{tabular}{|c|c|l|l|r|r|}
\hline NOMOR & NO TRANSAK & \multicolumn{1}{|c|}{ TANGGAL } & \multicolumn{1}{|c|}{ NAMA_BARANG } & QT & HARGA \\
\hline 1 & 1 & Januari - 18 & INDOMILK LIQ MELON BTL 190ML & 2 & 3,802 \\
\hline 2 & 2 & Januari - 18 & PUCUK HARUM TEH PET 35OML 24 & 4 & 2,865 \\
\hline 3 & 3 & Januari - 18 & GARUDA ROSTA K/P BW ANG 100G & 2 & 8,390 \\
\hline 4 & 4 & Januari - 18 & NN FANTASY STK RAINBOW 22.5G/144 & 1 & 3,196 \\
\hline 5 & 5 & Januari - 18 & ROTI SOBEK 6S PCS 1 & 3 & 8,000 \\
\hline 6 & 6 & Januari - 18 & FRESTEA G.TEA MADU PET 500ML & 2 & 5,080 \\
\hline 7 & 7 & Januari - 18 & FORTUNE PP 1 L/24 & 2 & 11,500 \\
\hline 8 & 8 & Januari - 18 & PSM GULA PREMIUM 1 KG & 2 & 12,500 \\
\hline 9 & 8 & Januari - 18 & SUNLIGHT PLUS A.BAK REF 800ML & 1 & 17,075 \\
\hline 10 & 9 & Januari - 18 & SGM EKSPLOR 1+ VANILLA 600 GR & 1 & 51,300 \\
\hline 11 & 10 & Januari - 18 & BONEETO CHOCOLATE 350G & 1 & 39,165 \\
\hline 12 & 11 & Januari - 18 & CB NIPPLE JAR MIX 18S & 1 & 5,108 \\
\hline 247192 & 92834 & Desember- 19 & BELFOODS SOSIS AYAM 375GR & 2 & 1 \\
\hline
\end{tabular}

Dari Proses transformasi data, menghasilkan perubahan untuk bagian data transaksi yang sebelumnya berbentuk identitas kode nomor transaksi berubah ke dalam bantuk urutan nomor transaki. 


\subsubsection{Data Mining}

Pada tahapan data mining dilakukan simulasi penghitungan data dengan penggunan dari data penjualan dimulai sejak tahun 2018 hingga tahun 2019, berdasarkan jangka waktu prediksi untuk enam bulan kedepan. Adapun yang pertama-tama yang harus dilakukan adalah mencari nilai dari:

$\left|\begin{array}{lccc}\sum \mathrm{Y} & \sum \mathrm{X} 1 & \sum \mathrm{X} 1^{2} & \sum \mathrm{X} 1 \mathrm{Y} \\ \sum \mathrm{X} 2 & \sum \mathrm{X} 2^{2} & \sum \mathrm{X} 1 . \mathrm{X} 2 & \sum \mathrm{X} 2 \mathrm{Y}\end{array}\right|$

Tabel 4. Akumulasi Data Penjualan Per 6 Bulan Beserta Nilai Dari $\sum Y, \sum X 2 \& \sum X 1$

\begin{tabular}{|l|c|c|c|}
\hline \multicolumn{1}{|c|}{ Bulan - Tahun } & Jumlah Pendapatan (X2) & Jumlah Transaksi (X1) & Jumlah penjualan Barang (Y) \\
\hline Januari - Juni 2018 & 1245725790 & 25318 & 107044 \\
\hline Juli - Desember 2018 & 998148367 & 23754 & 83863 \\
\hline Januari - Juni 2019 & 1031502851 & 23029 & 81543 \\
\hline Juli - Desember 2019 & 780362729 & 20733 & 66980 \\
\hline \multirow{2}{*}{ Jumlah } & $\mathbf{4 0 5 5 7 3 9 7 3 7}$ & $\mathbf{9 2 8 3 4}$ & $\mathbf{3 3 9 4 3 0}$ \\
\hline
\end{tabular}

Tabel 5. Akumulasi Nilai Dari $\sum \mathrm{X} 1 . \mathrm{X} 2, \sum \mathrm{X} 1^{2}, \sum \mathrm{X} 2^{2}, \sum \mathrm{X} 1 \mathrm{Y}, \& \sum \mathrm{X} 2 \mathrm{Y}$

\begin{tabular}{|c|c|c|c|c|}
\hline $\mathbf{X 1}^{\mathbf{2}}$ & $\mathbf{X 1 . X 2}$ & $\mathbf{X 1 . Y}$ & $\mathbf{X 2}^{\mathbf{2}}$ & $\mathbf{X} 2 . \mathbf{Y}$ \\
\hline 641001124 & 31539285551220.00 & 2710139992.00 & 1551832743871120000.00 & 133347471464760.00 \\
\hline 564252516 & 23710016309718.00 & 1992081702.00 & 996300162544767000.00 & 83707716501721.00 \\
\hline 530334841 & 23754479155679.00 & 1877853747.00 & 1063998131621130000.00 & 84111836979093.00 \\
\hline 429857289 & 16179260460357.00 & 1388696340.00 & 608965988812327000.00 & 52268695588420.00 \\
\hline $\mathbf{2 1 6 5 4 4 5 7 7 0}$ & $\mathbf{9 5 1 8 3 0 4 1 4 7 6 9 7 4 . 0 0}$ & $\mathbf{7 9 6 8 7 7 1 7 8 1}$ & $\mathbf{4 2 2 1 0 9 7 0 2 6 8 4 9 3 5 0 0 0 0 . 0 0}$ & $\mathbf{3 5 3 4 3 5 7 2 0 5 3 3 9 9 4 . 0 0}$ \\
$\mathbf{\Sigma X 1}^{\mathbf{2}}$ & $\mathbf{\Sigma X 1 . X 2}$ & $\mathbf{X X 1 . Y}$ & $\mathbf{X X 2}^{\mathbf{2}}$ & $\mathbf{\Sigma X 2 . Y}$ \\
\hline
\end{tabular}

Dari proses penghitungan yang telah dilakukan maka diperoleh nilai dari $\sum \mathrm{Y}, \sum \mathrm{X} 1, \sum \mathrm{X} 1^{2}, \sum \mathrm{X} 2^{2}, \sum \mathrm{X} 1 \mathrm{Y}$, $\sum \mathrm{X} 2 \mathrm{Y} \& \sum \mathrm{X} 1 . \mathrm{X} 2$. Berikutnya adalah mencari nilai dari A0, A1, A2 dan A3.

Tebel 6. Data A0

\begin{tabular}{|c|c|c|c|}
\hline \multirow{2}{*}{$\mathrm{A} 0=$} & $\mathrm{n}$ & $\sum \mathrm{X} 1$ & $\sum \mathrm{X} 2$ \\
\cline { 2 - 4 } & $\sum \mathrm{X} 1$ & $\sum \mathrm{X} 1^{2}$ & $\sum \mathrm{X} 1 . \mathrm{X} 2$ \\
\cline { 2 - 4 } $\mathrm{*} 0$ & $\sum \mathrm{X} 2$ & $\sum \mathrm{X} 1 . \mathrm{X} 2$ & $\sum \mathrm{X} 2^{2}$ \\
\hline \multirow{2}{*}{$=$} & 4 & 2165445770 & 9055739737 \\
\cline { 2 - 4 } & 92834 & 95183041476974.00 & 4221097041476974.00 \\
\hline
\end{tabular}

Tabel 7. Data A1

\begin{tabular}{|c|c|c|c|}
\hline \multirow{3}{*}{$\mathrm{A} 1=$} & $\sum \mathrm{Y}$ & $\sum \mathrm{X} 1$ & $\sum \mathrm{X} 2$ \\
& $\sum \mathrm{X} 1 \mathrm{Y}$ & $\sum \mathrm{X} 1^{2}$ & $\sum \mathrm{X} 1 . \mathrm{X} 2$ \\
\cline { 2 - 4 } & $\sum \mathrm{X} 2 \mathrm{Y}$ & $\sum \mathrm{X} 1 . \mathrm{X} 2$ & $\sum \mathrm{X} 2^{2}$ \\
\hline \multirow{3}{*}{$\mathrm{A} 1=$} & 339430 & 92834 & 4055739737 \\
& 7968771781 & 2165445770 & 95183041476974.00 \\
\cline { 2 - 4 } & $3.53436 \mathrm{E}+14$ & 95183041476974.00 & 4221097026849350000.00 \\
\hline
\end{tabular}

Tabel 8. Data A2

\begin{tabular}{|c|c|c|c|}
\hline \multirow{3}{*}{$\mathrm{A} 2=$} & $\mathrm{n}$ & $\sum \mathrm{Y}$ & $\sum \mathrm{X} 2$ \\
\cline { 2 - 4 } & $\sum \mathrm{X} 1$ & $\sum \mathrm{X} 1 \mathrm{Y}$ & $\sum \mathrm{X} 1 . \mathrm{X} 2$ \\
\cline { 2 - 4 } & $\sum \mathrm{X} 2$ & $\sum \mathrm{X} 2 \mathrm{Y}$ & $\sum \mathrm{X} 2^{2}$ \\
\hline \multirow{3}{*}{$\mathrm{A} 2=$} & 4 & 339430 & 4055739737 \\
& 92834 & 7968771781 & 95183041476974.00 \\
\hline & 4055739737 & 353435720533994.00 & 4221097026849350000.00 \\
\hline
\end{tabular}


Tabel 9. Data A3

\begin{tabular}{|c|c|c|c|}
\hline \multirow{3}{*}{ A3 $=$} & $\mathrm{n}$ & $\sum \mathrm{X} 1$ & $\sum \mathrm{Y}$ \\
& $\sum \mathrm{X} 1$ & $\sum \mathrm{X} 1^{2}$ & $\sum \mathrm{X} 1 \mathrm{Y}$ \\
\cline { 2 - 4 } & $\sum \mathrm{X} 2$ & $\sum \mathrm{X} 1 . \mathrm{X} 2$ & $\sum \mathrm{X} 2 \mathrm{Y}$ \\
\hline \multirow{3}{*}{$\mathrm{A} 3=$} & 4 & 92834 & 339430 \\
& 92834 & 2165445770 & 7968771781 \\
\cline { 2 - 4 } & 4055739737 & 95183041476974.00 & 353435720533994.00 \\
\hline
\end{tabular}

Setelah proses penghitungan untuk menentukan nilai dari rumus A0, A1, A2 dan A3 berhasil didapatkan maka proses selanjutnya adalah melakukan perhitungan data tersebut untuk mendapatkan nilai A0, A1, A2 dan A3.

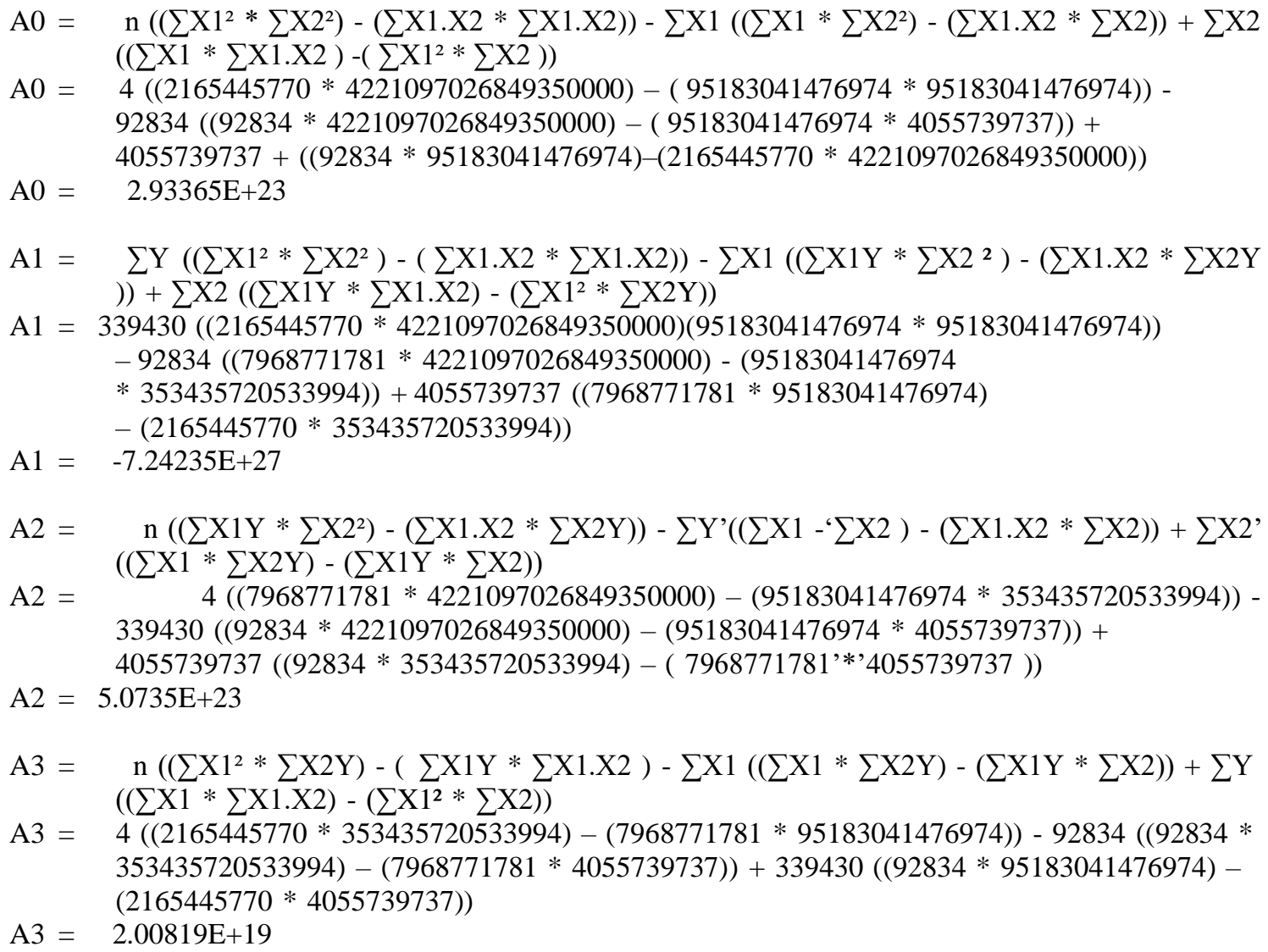

Dari proses penghitungan maka didapatkanlah nilai dari A0, A1, A2 dan A3 langkah selanjutnya adalah mencari nilai dari a, b1 dan b2.

$$
\begin{aligned}
& \mathrm{a}=" \frac{\mathrm{A} 1}{\mathrm{~A} 0} \\
& \mathrm{a}=\frac{-7.24235 \mathrm{E}+27}{2.93365 \mathrm{E}+23} \\
& \mathrm{a}=-24687.1415 \\
& \mathrm{~b} 1=\frac{\mathrm{A} 2}{\mathrm{~A} 0} \\
& \mathrm{~b} 1=\frac{5.0735 \mathrm{E}+23}{2.93365 \mathrm{E}+23} \\
& \mathrm{~b} 1=1.729412782 \\
& \mathrm{~b} 2=\frac{\mathrm{A} 3}{\mathrm{~A} 0}
\end{aligned}
$$


$\mathrm{b} 2=\frac{2.00819 \mathrm{E}+19}{2.93365 \mathrm{E}+23}$

b2 $=0.000068453667585576$

Setelah dilakukan perhitungan makan didapatkan nilai nilai dari koefisien yaitu sebagai berikut:

$\mathrm{a}=-24687.142$

$\mathrm{b} 1=1.72941278$

b2 $=0.000068453667585576$

Sehingga didapatlah persamaan regresi linier berganda sebagai berikut:

$$
Y=-24687.142+1.72941278 * X 1+0.000068453667585576 * X 2
$$

\subsection{Hasil}

Sebelumnya telah dilakukan proses prediksi secara manual untuk menentukan jumlah penjualan barang dalam kurun waktu 6 bulan kedepan, selanjutnya dilakukan prediksi menggunakan menggunakan aplikasi Rapidmider sebagai alat bantu dalam melakukan prediksi penjualan barang. Proses prediksi dibagi menjadi tiga yakni prediksi berdasarkan penjualan per-tahun, per-barang dan prediksi untuk mengukur tingkat kesalahan. Berikut ini adalah proses prediksi menggunakan tool Rapidminer:

\subsubsection{Prediksi Per-Tahun}

Proses prediksi penjualan per-tahun dilakukan untuk mencari nilai prediksi barang dalam kurun waktu satu tahun kedepan. Berikut ini adalah tampilan dari proses prediksi penjualan per-tahun menggunakan aplikasi rapidminer:

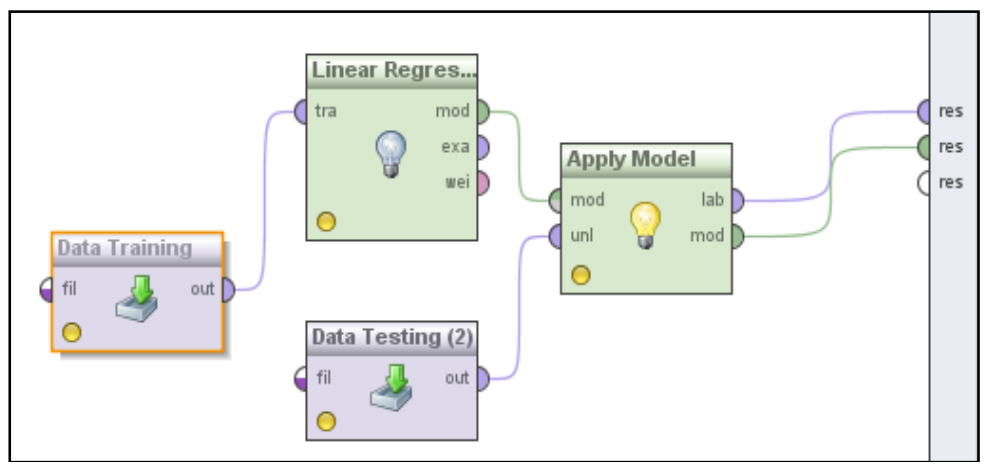

Gambar 4. Proses Prediksi Dengan Tool Rapidmir

Pada proses prediksi penjualan barang per-tahun ada 4 operator yang digukan yakni, operator input data (training), input data (testing), linier regression dan apply model. Adapun hasil dari prediksi sebagai berikut:

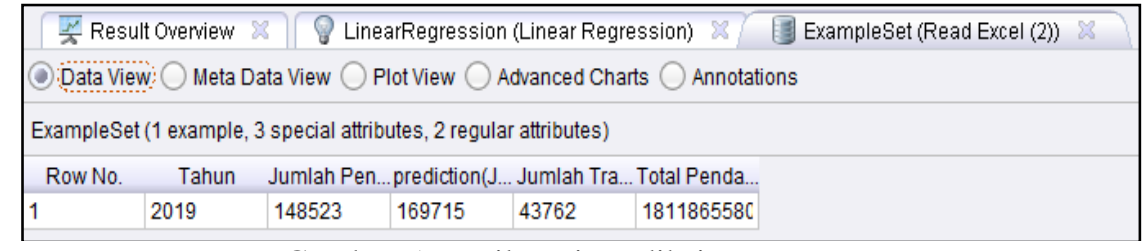

Gambar 5. Hasil Dari Prediksi Per-Barang

Hasil dari proses prediksi penjualan per-barang pada priode tahun 2020 yakni, 169725 barang.

\subsubsection{Prediksi Per-Barang}

Proses prediksi penjulan per-barang bertujuan untuk mencari nilai penjualan berdasarkan jenis barang, adapun proses dari prediksi per-barang mempunyai kesamaan dengan proses prediksi per-barang, yang 
membedakan adalah dari segi data yang diinputkan kedalam operator data (training), input data (testing). Berikut ini merupakan hasil dari kegiatan prediksi dengan memakai tool rapidminer:

\begin{tabular}{|c|c|c|c|c|c|}
\hline \multicolumn{6}{|c|}{ (-) Data View $\bigcirc$ Meta Data View $\bigcirc$ plot View $\bigcirc$ Advanced charts $\bigcirc$ Annotations } \\
\hline \multicolumn{6}{|c|}{ Exampleset ( 15 examples, 1 special attribute, 4 regular attributes) } \\
\hline \multicolumn{6}{|c|}{ Row No. prediction (J... Nama Bara... Jumlah Tra... Pendapata... Jumlah pen... } \\
\hline 1 & 73.057 & ABC KACAN & 71 & 248500 & 131 \\
\hline 2 & 419.494 & FORTUNEP & 233 & 2665500 & 420 \\
\hline 3 & 306.153 & FORTUNES & 180 & 3931200 & 246 \\
\hline 4 & 408.801 & INDOMIE GC & 228 & 696000 & 510 \\
\hline 5 & 154.320 & SOVIA MINY & 109 & 2445500 & 154 \\
\hline 6 & 284.768 & INDOMIE GC & 170 & 430000 & 319 \\
\hline 7 & 68.780 & BERAS PATI & 69 & 7728000 & 85 \\
\hline 8 & 130.797 & SUPERMI AI & 98 & 294000 & 171 \\
\hline 9 & 177.844 & INDOMIE CE & 120 & 363000 & 254 \\
\hline 10 & 402.386 & ALFA $330 \mathrm{ML}$ & 225 & 466000 & 348 \\
\hline 11 & 23.872 & TEH BOTOL & 48 & 144000 & 107 \\
\hline 12 & 70.919 & OREO C/S/C & 70 & 620500 & 74 \\
\hline 13 & 137.212 & ADEM SARI I & 101 & 656500 & 119 \\
\hline 14 & 141.489 & SEDAAP MIE & 103 & 260000 & 202 \\
\hline 15 & 132.935 & TEH GELAS & 99 & 381500 & 123 \\
\hline
\end{tabular}

Gambar 6. Hasil prediksi Per-Barang

Dari proses prediksi yang telah dilakukan menghasilkan nilai prediksi penjualan per-barang dengan jenis penjualan barang yang paling tinggi yakni FORTUNE PP 1 L/24 yang mempunyai angka prediksi 419,494 barang \& menghasilkan nilai prediksi terendah untuk jenis barang TEH BOTOL KOTAK SOSRO 200 ML yang mempunyai angka prediksi 23,872 barang.

\subsubsection{Pengukuran Tingkat Kesalahan (error)}

Proses pengukuran data atau root mean square error (RMSE), bertujuan untuk mengetahui jarak nilai prediksi dengan kenyataannya. Adapaun prosesnya antara lain:

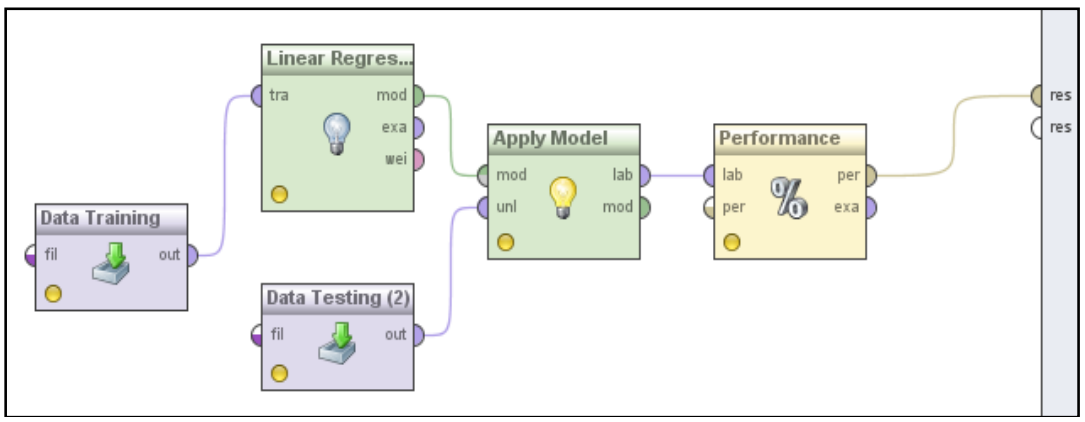

Gambar 7. Proses Prediksi Pengukuran Tingkat Kesalahan

Tahapan dalam proses pengukuran dari tingkat kesalahan mempunyai kesamaan dengan proses prediksi penjualan barang per-barang maupun per-tahun, yang membedakannya adalah adanya penambahan 1 operator baru yakni operator performance, operator ini berguna untuk mengukur nilai RSME dari prediksi yang dilakukan. Adapun hasil dari proses ini antara lain:

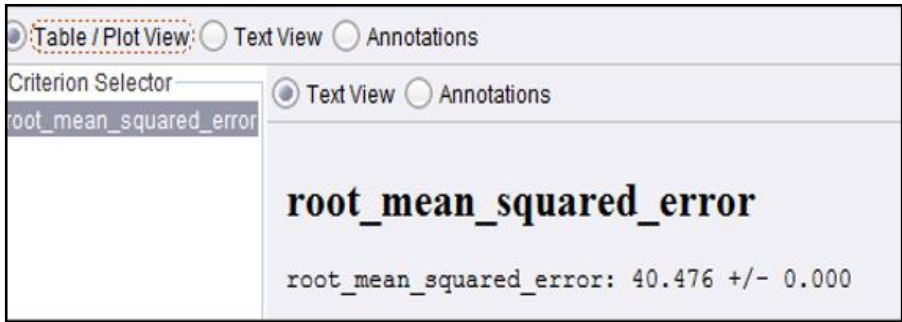

Gambar 8. Nilai RMSE 
Dari proses prediksi yang dilakukan untuk mengukur niali dari RMSE, menghasilkan nilai RMSE sebesar 40,476 .

\section{Kesimpulan}

Prediksi penjualan barang menggunakan algoritma regresi linier dengan proses pengolahan data menggunakan tahapan dari Knowledge Discovery In Database (KDD), serta penggunaan tool rapidminer sebagai alat bantu dalam proses prediksi barang menghasilkan:

a. Hasil yang diperoleh dari prediksi penjualan barang untuk priode waktu tahun 2020 sebesar 169715 barang.

b. Dari proses pediksi penjualan berdasarkan jenis barang menghasilkan nilai penjualan barang tertinggi yaitu berjenis barang FORTUNE PP $1 \mathrm{~L} / 24$, yang memiliki angka prediksi penjualan barang sebesar 419,494 \& menghasilkan nilai penjualan barang terendah untuk jenis barang TEH BOTOL KOTAK SOSRO 200 ML dengan angka 23,872 barang.

c. Pengukuran tingkat error, diperoleh nilai dari Root Mean Square Error (RMSE) dengan nilai 40,476.

\section{References}

[1] A. K. ASLAM, "Pengaruh pertumbuhan minimarket terhadap minat dan kebiasaan belanja masyarakat di kelurahan tamamaung kota makassar," 2017.

[2] N. L. P. Wulandari, N. L. A. K. Y. Sarja, and I. G. A. D. Saryanti, "Prediksi Jumlah Pelanggan Dan Persediaan Barang Menggunakan Metode Regresi Linier Berganda Pada Bali Orchid," Eksplora Inform., pp. 1-12, 2014.

[3] I. K. Juni Arta, G. Indrawan, and G. R. Dantes, "Data Mining Rekomendasi Calon Mahasiswa Berprestasi Di Stmik Denpasar Menggunakan Metode Technique for Others Reference By Similarity To Ideal Solution," JST (Jurnal Sains dan Teknol., vol. 5, no. 2, p. 792, 2017, doi: 10.23887/jst-undiksha.v5i2.8549.

[4] N. A. Hasibuan et al., "Implementasi Data Mining Untuk Pengaturan Layout," vol. 4, no. 4, pp. 6-11, 2017.

[5] M. Irfan, L. P. Ayuningtias, and J. Jumadi, "Analisa Perbandingan Logic Fuzzy Metode Tsukamoto, Sugeno, Dan Mamdani ( Studi Kasus : Prediksi Jumlah Pendaftar Mahasiswa Baru Fakultas Sains Dan Teknologi Uin Sunan Gunung Djati Bandung)," J. Tek. Inform., vol. 10, no. 1, pp. 9-16, 2018, doi: 10.15408/jti.v10i1.6810.

[6] S. Haryati, A. Sudarsono, and E. Suryana, "Implementasi Data Mining Untuk Memprediksi Masa Studi Mahasiswa Menggunakan Algoritma C4.5 (Studi Kasus: Universitas Dehasen Bengkulu)," J. Media Infotama, vol. 11, no. 2, pp. 130-138, 2015.

[7] D. S. Kusumo, M. A. Bijaksana, and D. Darmantoro, "Data Mining Dengan Algoritma Apriori Pada Rdbms Oracle," TEKTRIKA - J. Penelit. dan Pengemb. Telekomun. Kendali, Komputer, Elektr. dan Elektron., vol. 8, no. 1, pp. 1-5, 2016, doi: 10.25124/tektrika.v8i1.215.

[8] M. Syafruddin, L. Hakim, and D. Despa, "Metode Regresi Linier Untuk Prediksi Kebutuhan Energi Listrik Jangka Panjang (Studi Kasus Provinsi Lampung),” J. Inform., vol. 2, no. 1, pp. 19 , 2014 , [Online].

Available: http://journal.eng.unila.ac.id/index.php/jitet/article/download/237/228.

[9] A. Purwanto et al., "Perbandingan Minat Siswa Smu Pada Metode Klasifikasi Menggunakan 5 Algoritma," vol. 2, no. 1, pp. 43-47, 2018. 